Umbundu Kinship and Character

Being a Description of the Social Structure and Individual Development of the Ovimbundu of Angola, with Observations concerning the Bearing on the Enterprise of Christian Missions of certain Phases of the Life and Culture Described. By Gladwyn Murray Childs. (Published for the International African Institute and the Witwatersrand University Press.) Pp. xviii $+246+16$ plates. (London, New York and Toronto : Oxford University Press, 1949.) 21s. net.

HIS is a useful study of the Mbundu, alias

Ovimbundu, the largest and most vigorous tribal group in the Portuguese colony of Angola. The manuscript was completed ten years ago, and it is a pity that it could not have been published before; as it helps to fill a serious gap in our knowledge of this part of south-western Africa. It will be of considerable value not only to missionaries and those concerned with the government of this territory, but also to anthropologists, particularly those concerned with the study of social organisation and of social psychology.

The book contains three sections : the first dealing with the kinship structure and the bilateral aspects of Mbundu lineages; the second with the mental development and education of the individual in Mbundu society; and the third with Mbundu history. Those interested in the comparative study of southern Bantu peoples will find these studies extremely useful, but will probably share the reviewer's regret that the author has tried to compress into a book of 220 -odd pages material that could well have gone into three volumes. As a result, certain sections of the book, particularly those dealing with kinship organisation, are obscure and lacking in explanatory details.

The editing is of the usual high standard set by publications of the International African Institute, although one wonders why the editor should want to increase publication costs by including plates of wounded bull elands, decapitated wart hogs and similar subjects having no relation to the text.

\section{The Yeast Cell}

Its Genetics and Cytology. By Carl C. Lindgren. Pp. xviii $+358+7$. (Saint Louis : Educational Publishers, Inc., 1949.) n.p.

7 HERE are many forms of life, once thought to be unusual, or even unique in their structure and functions, which have afterwards proved to be more orthodox than they were believed to be. So, in the case of yeasts, this book shows them to be conventional cells, possessing chromosomes, centrosomes and mitochondria, and behaving cytologically and genetically like any other cell. There are, indeed, aspects of the genetical behaviour of yeasts, especially the apparently jrregular segregation of allelomorphs in certain cases, which may appear to support the heterodoxy which is sometimes claimed for them; but even in these cases, the author has abandoned the hypothesis of the maintenance, under the influence of a specific substrate, of a fermentative character for which no gene is present. He has also brought experimental evidence to reinforce the classical view of the importance of the chromosome, while revising and developing the concept of the physical nature of the gene.

The majority of the material is derived from the researches of the author and his associates, and the book is accordingly very profusely illustrated by plates, diagrams and tables. These suffer considerably from the off-set printing technique which, together with the unusual method of numbering the pages by chapters, gives the entire book an unfamiliar appearance. A more serious defect is the absence of an index, which is difficult to forgive in a work of this nature.

In view of the great and growing debt of enzyme chemistry and of genetics to the study of the yeast cell, the value of the book is unquestionable, and the field which it covers is wider than the subtitle suggests.

K. A. Bisset

The Living Soil

Evidence of the Importance to Human Health of Soil Vitality, with Special Reference to National Planning. By E. B. Balfour. Revised edition. Pp. $270+14$ plates. (London: Faber and Faber, Ltd., 1949.) 15s. net.

7 HIS beautifully produced book diligently pre. sents the faith of a sect which holds that 'vitality' of soil is important for human health. Incorruptibility can be approached through use of compost and organic manures on terms which the book sets out.

The exposition is sincere, but will have little interest to the man of science unless he be a sociologist. It would be a mistake to judge by orthodox scientific standards the tenets of this biologically based cult which freely uses the terminology of science but rejects its methodology, which confuses testimony with evidence and has a primitive approach to experimentation. The pseudo-scientific approach is exemplified by reliance on vitamin $B$ as understood c. 1929. The book may be useful for its information about the Soil Association and the composition and aims of the Haughley Research Trust which was established to put compost-farming to the proof. It reveals a tangled, kindly web of thought, which deceives nobody except its spinners and voluntary adherents in search of comfort for their souls. Such people are more numerous than men of science; and it would be surprising if the book were not a success.

Hugr NrCOI

Fish and Fish Inspection

By John D. Syme. Pp. viiit 162. (London : H. K. Lewis and Co., Ltd., 1949.) 18s. net.

7 HIS book has been written primarily for the use of food inspectors and students preparing for the certificate of the Royal Sanitary Institute. It begins with brief descriptions of modern fishing-vessels and gear, and of the various fishing-grounds on which they work. Then follows an important chapter on how to identify the various species of fish commonly met with in British fish-markets and on fishmongers' slabs. The deseriptions are expressed in plain language and each is accompanied by a black-andwhite drawing of the species mentioned. The exclusion of all scientific terms from the descriptions is probably an advantage for non-specialists, but even they would certainly have benefited if at least the scientific names had been given in addition to the common names by which the different kinds are known to the trade.

Chapters on fish inspection, preparation and transport, and the various methods of fish processing appear to be adequate for the purpose. The book is well produced in an attractive format and should have a ready sale in trade circles. G. A. Steven 